\title{
The Influence of Financial Crime on Tax Compliance: Moderating Effect of Government's Future Orientation
}

\author{
Zahra Jihadia El Fitria Ramadhani ${ }^{1}$, Ari Budi Kristanto ${ }^{2}$ \\ Faculty of Economics and Business, Satya Wacana Christian University, INDONESIA ${ }^{1,2}$
}

\begin{tabular}{l}
\hline \hline ARTICLE INFO \\
\hline \hline Article history: \\
Received: Dec 15,2021 \\
Revised: Feb 3, 2022 \\
Accepted: Feb 15, 2022 \\
\hline Keywords: \\
Financial crime; Future \\
Orientation of Government; \\
Tax Compliance \\
\hline Correspondence: \\
Ari Budi Kristanto2 \\
Ari.kristanto@ uksw.edu
\end{tabular}

How to cite (APA Style):

Ramadhani, Z.J.E.F., Kristanto, A.B. (2022). The Influence of Financial Crime on Tax Compliance: Moderating Effect of Government's Future Orientation. Jurnal Akuntansi, 12(1), 1-12 https://doi.org/10.33369/j.akuntansi.12.1.1-12 \begin{abstract}
Taxes have become the primary source of revenue for most countries all over the globe. However, financial crime occurs in many parts of the world and may threaten this critical role of tax. This research aims to examine the influence of financial crime on tax compliance with the future orientation of the government as a moderating variable. This research is a cross-country research with a population of countries in the world. By using purposive sampling, the sample of this research is 105 countries. This research obtained secondary data to measure the country-level financial crime, tax compliance, and the government's future orientation. To test the hypothesis, the data is then analyzed using moderated regression analysis (MRA). The results indicate that financial crime has a negative influence on tax compliance. Financial crimes can undermine a culture of compliance which can reduce tax compliance. The higher the financial crime, the lower the tax compliance. Furthermore, the future orientation of government can weaken the negative influence of financial crime on tax compliance. When the government has a future orientation that shows the government's ability to prepare for the future for its welfare, people will tend to trust the government. The higher the trust, the higher the tax compliance so that government can still strive for tax compliance. This research contributes to providing information for the government in determining orientation strategies in response to the conditions of financial crimes that occur so that the government can still strive for tax compliance to maintain government revenue. The study's shortcomings include that it used data from many sources and years. As a result, readers should use caution when interpreting the research's findings, and the subsequent researchers should get data from the same year.
\end{abstract}

\section{INTRODUCTION}

Governments collect revenue to finance the state and income redistribution (OECD, 2019; Varvarigos, 2017). Government revenue consists of taxes, non-tax revenues, social contributions, and grants (ICTD/UNU-WIDER, 2020). Based on the Government Revenue Dataset 2020, most countries impose taxes as the primary source of revenue, so taxes are essential for countries globally (ICTD/UNU-WIDER, 2020). Tax revenue received can be influenced by several factors and one of which is tax compliance.

Tax compliance is when taxpayers pay the tax correctly and on time which shows their obedience to the tax laws and regulations (Youde \& Lim, 2019; Long et al., 1991; Devos, 2014). Tax compliance is also a condition where taxpayers fulfill their tax obligations (Nurkhin et al., 2018). Moreover, according to the OECD (2010) in Borrego et al. (2013), the following 4 points determine taxpayer compliance: registering for tax purposes, reporting correct tax obligations, filing tax returns, and paying taxes on time. However, tax non-compliance, a condition where the taxpayers do not fulfill the tax obligations and do not comply with tax regulations by taking actions such as tax evasion, can reduce tax revenue which results in loss of government revenue (Randlane, 2015; Junpath et al., 2016; Handoyo \& Candrapuspa, 2017; Borrego et al., 2013; Kumar, 2012). 
The Influence of Financial Crime on Tax Compliance: Moderating Effect of Government's Future Orientation

Zahra Jihadia El Fitria Ramadhani and Ari Budi Kristanto

According to Barbuta-misu (2011), taxpayers tend to be less compliant if they have a positive perspective on tax evasion. According to (Murphy, 2011) in Schneider et al. (2015), it stated that there are losses experienced by 145 countries due to tax evasion with an estimate of USD 3.1 trillion in 2010. Moreover, according to the report of The State of Tax Justice 2021, it stated that countries worldwide lost $\$ 483$ billion because of the tax abuse that is done by both corporate and individual taxpayers (Tax Justice Network, 2021). It also shows that tax noncompliance happens around the world and impacts revenue globally. Therefore, it is necessary to improve tax compliance to maintain government revenues.

However, financial crimes can cause losses as well, this financial crime is a non-violent crime that causes financial loss (IMF, 2001). Financial crime relates to the illegal conversion of other people's property for personal gain (Jung \& Lee, 2017; Gottschalk, 2010). Financial crime can include money laundering, bribery and corruption, fraud, terrorist financing, insider trading, and stock manipulation (Jung \& Lee, 2017). Money laundering is part of financial crime and is related to crimes that produce illegal profit because it is a process of disguising the origins of money obtained from illegal action or severe crime such as terrorist activity, drug trafficking, corruption, and bribery to make it look like it comes from a legitimate source (Kumar, 2012; Amara \& Khlif, 2018; United Nation, 2005). Therefore, since the authorities do not know this, the offender can still enjoy the gains.

According to Kar \& Spanjers (2015), from 2004 to 2013, developing countries lost US\$7.8 trillion in illegal financial flows. Other than that, the Basel AML Index 2020 report shows that 6 out of 8 regions in the world have some regional scores in the five areas of risk assessment for money laundering and terrorist financing (ML/TF) above the global average (Basel Institute on Governance, 2020). Furthermore, The Secretary-General of the United Nations, António Guterres, said that corruption causes international losses of \$3.6 trillion annually (Johnson, 2018). Thus, it can be concluded that financial crime occurs in almost all parts of the world and harms countries globally.

According to Amara \& Khlif (2018), money laundering shows low conformity to state regulations. It means that someone who commits financial crimes may have low compliance with tax regulations as it is one of the state regulations. Not only society but also governments can commit financial crimes such as corruption. Corruption carried out by the government in a country shows that the government is dishonest and can reduce public trust in the government. People will tend not to pay their taxes and it can lead to lower tax compliance. Moreover, if the government has a low commitment to eradicating financial crime, it will discourage compliant taxpayers from complying with tax legislation and lead to tax non-compliance (Amara \& Khlif, 2018).

It shows that there is a link between financial crimes and tax compliance in which financial crimes can lead to low tax compliance (Amara \& Khlif, 2018). Money laundering describes the low tax morale and conformity to the state regulations that will result in low tax compliance (Amara \& Khlif, 2018; Mayowan, 2019). Other than that, according to Aghion et al. (2016) in Baum et al. (2017), corruption can damage the culture of compliance. La Porta et al. (1999) and Wu \& Teng (2005) stated that higher tax compliance comes from countries that are less or not too corrupt and vice versa. Therefore, based upon the explanation above, the formulation of the first hypothesis is:

$H_{1}$ : Financial crime has a negative influence on tax compliance

Tax compliance needs to be improved to maintain tax revenue. Tax compliance can be improved by the benefits of public goods received by the society as a result of their tax payments (Alm et al., 1992). Furthermore, according to Picur \& Riahi-Belkaoui (2006) in (Khlif et al., 2016), people will comply with taxes if the government provides them with conditions such as 
increasing and protecting their human dignity, fueling their morality, and respecting moral norms. According to Khlif et al. (2016), the strong commitment of the government to improving welfare through sustainability can push taxpayers to comply with tax legislation where the higher the level of sustainability, the higher the tax compliance. Sustainability shows the future orientation of government (World Economic Forum, 2019). It shows the government's performance in serving society for its welfare. With the services provided, the government can build public trust. The higher the trust, the greater the citizen's motivation to comply with the regulation (Stephens et al., 2019). When people comply with tax regulations, it shows their compliance with tax. Therefore, these things imply that the future orientation of the government can influence tax compliance.

Future orientation is the capability to determine goals, plans, and actions for the future (Johnson et al., 2014; Seginer \& Noyman, 2005; Wentworth, 2008). According to Lewin (1926) in Petutschnig (2017), high future orientation is indicated by the ability of individuals to see possibilities in the future, set goals, and make strategies to achieve these goals. It shows that future orientation includes looking ahead (Carmi \& Arnon, 2014). Moreover, the government can have a future orientation which according to the World Economic Forum (2018), the future orientation of government is the government's capability to prepare for the future. Therefore, it shows that the future-oriented government is aware of the possibilities that will occur in the future. The government is making efforts and strategies to prepare for it. Hence, it can be said that the government is serving society for its welfare. The government can build public trust with the services provided and lead society to comply with regulations in which trust can rise compliance (World Economic Forum, 2020; Stephens et al., 2019; Birskyte, 2014; K. Murphy, 2004). It indicates that when a society complies with tax regulation, it shows that they are compliant with tax. In addition, the higher the public trust in the government, the higher the tax compliance (Birskyte, 2014). Therefore, even though financial crimes occur in a country, when the government has future orientation, the researcher expects that the perpetrators of financial crimes or other taxpayers will respect it by complying with the tax regulation. Hence, the government can still strive for tax compliance.

According to Khlif et al. (2016), sustainability can influence tax compliance where the higher the level of sustainability, the higher the tax compliance. When the government has a strong commitment to improving welfare through sustainability, it can push the taxpayers to comply with tax legislation (Khlif et al., 2016). Therefore, the future orientation of government tends to weaken the influence of financial crime towards tax compliance. Based on this explanation, the formulation of the second hypothesis in this research is as follows:

\section{$\mathrm{H}_{2}$ : The future orientation of government can reduce the negative influence of financial crime on tax compliance}

This research aims to examine the influence of financial crime on tax compliance with the future orientation of government as a moderating variable. Previous research about the influence of financial crime on tax evasion has been done by Amara \& Khlif. Since no previous research has examined the connection of between future orientation of government on financial crime and tax compliance yet, therefore, this research adds the future orientation of government as the moderating variable to close the gap to determine whether it can maintain tax compliance. The importance of this research is to provide information for the government in determining orientation strategies in response to the conditions of financial crimes that occur so that the government can still strive for tax compliance to maintain tax revenue as the main source of government revenue. Moreover, this research can be a reference for future research that examines topics related to financial crime, tax compliance, and the future orientation of government. 
The Influence of Financial Crime on Tax Compliance: Moderating Effect of Government's Future

Orientation

Zahra Jihadia El Fitria Ramadhani and Ari Budi Kristanto

\section{RESEARCH METHOD}

Population and Sample

This is quantitative research that includes a population of countries across the world. The sample was obtained using a purposive sampling technique with the criteria of countries reported in Mawejje \& Sebudde (2019), Basel AML Index 2020 Report, and Global Competitiveness Report 2019. Thus, from 193 countries, a sample of 105 countries was obtained, as shown in Table 1.

Table 1. Sample

\begin{tabular}{lc}
\hline & Number of Countries \\
\hline Countries in the world & 193 \\
\hline Countries not reported in Mawejje \& Sebudde (2019) & $(43)$ \\
\hline Countries not reported in Basel AML Index 2020 Report & $(32)$ \\
\hline Countries not reported in Competitiveness Report 2019 & $(13)$ \\
\hline Sample & 105 \\
\hline Source: Data collected 2021 &
\end{tabular}

\section{Data dan Data Sources}

Secondary data with cross-country data in the form of information on tax compliance, financial crimes, and the future orientation of government was used. The tax compliance data was obtained from the tax effort based on Mawejje \& Sebudde (2019). For financial crime, the data was obtained from the score of money laundering/terrorist financing risk in the Basel AML Index 2020 Report. For the future orientation of government, the data was obtained from the score of the future orientation of government in the Global Competitiveness Report 2019. Operational Definition and Variable Measurement of this research, are below:

Table 2. Operational Definition

\begin{tabular}{|c|c|c|c|}
\hline Variable & Definition & Indicators & Source \\
\hline $\begin{array}{l}\text { Tax } \\
\text { Compliance }\end{array}$ & $\begin{array}{l}\text { A condition of a } \\
\text { country with tax } \\
\text { revenue realization } \\
\text { close to tax potential }\end{array}$ & Tax effort & $\begin{array}{l}\text { (Mawejje \& } \\
\text { Sebudde, } \\
\text { 2019) }\end{array}$ \\
\hline $\begin{array}{l}\text { Financial } \\
\text { Crime }\end{array}$ & $\begin{array}{l}\text { A non-violent crime } \\
\text { that causes financial } \\
\text { loss (IMF, 2001) }\end{array}$ & $\begin{array}{l}\text { 1. The quality of AML/CFT measures and } \\
\text { regulations } \\
\text { 2. Bribery and corruption } \\
\text { 3. Financial transparency and standards } \\
\text { 4. Public transparency and accountability } \\
\text { 5. Legal and political risks. }\end{array}$ & $\begin{array}{l}\text { (Basel Institute } \\
\text { on } \\
\text { Governance, } \\
2020 \text { ) }\end{array}$ \\
\hline $\begin{array}{l}\text { Future } \\
\text { Orientation of } \\
\text { Government }\end{array}$ & $\begin{array}{l}\text { The government's } \\
\text { ability to prepare for } \\
\text { the future }\end{array}$ & $\begin{array}{l}\text { 1. The government's ability to ensure a stable } \\
\text { policy environment } \\
\text { 2. The government's responsiveness to change } \\
\text { 3. How quickly the legal framework can adapt to } \\
\text { digital business } \\
\text { 4. The government's long-term vision } \\
\text { 5. Policies and regulations related to energy } \\
\text { efficiency } \\
\text { 6. Policies and regulations related to renewable } \\
\text { energy } \\
\text { 7. How many environmental agreements a } \\
\text { country has ratified }\end{array}$ & $\begin{array}{l}\text { (World } \\
\text { Economic } \\
\text { Forum, 2019) }\end{array}$ \\
\hline
\end{tabular}

\section{Dependent Variable}

The dependent variable in this research is tax compliance with the data obtained from the tax effort based on Mawejje \& Sebudde (2019). Tax effort shows the percentage to the extent of tax revenue realization of a country can reach its tax potential (Mawejje \& Sebudde, 2019). Tax potential is the maximal tax revenue a country can attain at a particular time by 
considering economic, social, demographic, and institutional factors (Mawejje \& Sebudde, 2019; Langford \& Ohlenburg, 2015; Fenochietto \& Pessino, 2013). The tax revenue of a country close to tax potential has low tax evasion, which shows low tax non-compliance (Fenochietto \& Pessino, 2013; Junpath et al., 2016; Handoyo \& Candrapuspa, 2017). It reveals that a country with high tax effort, which is shown in the tax revenue closer to the tax potential, also has high tax compliance. Thus, tax effort can be used to measure tax compliance. The tax effort value is expressed in percentage with a decimal range of 0-1. Tax effort close to 0 indicates low tax compliance, while tax effort close to 1 indicates high tax compliance.

\section{Independent Variable}

The financial crime data was taken from the money laundering/terrorist financing risk score in the Basel AML Index 2020 Report. Amara \& Khlif (2018) used this data in their research related to financial crime. The Basel AML Index 2020 Report is a report that presents a ranking of 141 countries in the world based on the money laundering/terrorist financing risk (Basel Institute on Governance, 2020). The score of money laundering/terrorist financing risk is in the range of 0 until 10. A score close to 0 indicates the low risk of money laundering/terrorist financing which shows low financial crime while a score close to 10 indicates the high risk of money laundering/terrorist financing which shows high financial crime (Amara \& Khlif, 2018).

\section{Moderating Variable}

The future orientation of government data was taken from the score of future orientation of government in the Global Competitiveness Report 2019. The Global Competitiveness Report measures the competitiveness of countries that shows the level of productivity achieved with the future orientation of government as one of its sub-pillars (World Economic Forum, 2019). The range of future orientation of government score is 0-100. A score close to 100 indicates the high future orientation of government and a score close to 0 indicates the low future orientation of government.

\section{Analysis Technique}

This research used Moderated Regression Analysis (MRA) to examine the moderating effect of the future orientation of government on financial crime and tax compliance using SPSS. SPSS is used as the analytical tool because the processed data presented is direct yet informative and it has been used by many researchers in analyzing the data. There are several stages in analyzing the data. First, after the data are collected, descriptive statistical analysis is carried out which then produces numerical information that will present the mean, range of scores (minimum and maximum), and standard deviation. After that, the researcher will perform a classical assumption test that includes normality, multicollinearity, and heteroscedasticity tests. The regression equation model of this research are as follows:

$\mathrm{TC}=\mathrm{a}+\mathrm{b}_{1} \mathrm{FC}+\mathrm{e} \ldots \ldots \ldots \ldots \ldots \ldots \ldots(1)$
$\mathrm{TC}=\mathrm{a}+\mathrm{b}_{1} \mathrm{FC}+\mathrm{b}_{2} \mathrm{FOG}+\mathrm{b}_{3} \mathrm{FC} * \mathrm{FOG}+\mathrm{e}$

Description:

$\begin{array}{ll}\mathrm{TC} & =\text { Tax compliance } \\ \mathrm{a} & =\text { Constant } \\ \mathrm{b} & =\text { Regression coefficient } \\ \mathrm{FC} & =\text { Financial crime } \\ \mathrm{FOG} & =\text { Future orientation of government } \\ \mathrm{FC} * \text { FOG } & =\text { Moderating variable } \\ \mathrm{e} & =\text { Error }\end{array}$


The Influence of Financial Crime on Tax Compliance: Moderating Effect of Government's Future Orientation

Zahra Jihadia El Fitria Ramadhani and Ari Budi Kristanto

The first hypothesis states that financial crime has a negative influence on tax compliance. Thus, the first hypothesis is accepted if the regression coefficient $\left(b_{1}\right)$ in Model 1 is negative and the significant value is $<0.05$. The second hypothesis states that the future orientation of government can reduce the negative influence or weaken the relationship between financial crime and tax compliance. Thus, the second hypothesis is accepted if the regression coefficient $\left(b_{3}\right)$ in Model 2 is negative and the significant value is $<0.05$. The interpretation of the results of the hypothesis testing is by looking at the regression coefficient and significance that has also been carried out by the previous researcher, namely Wardani \& Juliani (2018).

\section{RESULTS AND DISCUSSION}

Result

Researcher conducted a descriptive statistical analysis. This analysis was conducted to determine the characteristics of the variables. Table 3 below shows the results of descriptive statistical analysis with a sample size of 105 countries:

Table 3. Descriptive Statistics

\begin{tabular}{lrrrr}
\hline \multicolumn{1}{c}{ Variable } & \multicolumn{1}{c}{ Min. } & \multicolumn{1}{c}{ Max. } & \multicolumn{1}{c}{ Mean } & Std. Deviation \\
\hline Tax Compliance & 0.03 & 0.96 & 0.4774 & 0.15827 \\
Financial Crime & 2.36 & 7.82 & 5.0998 & 1.10995 \\
Future Orientation of & 23.40 & 81.30 & 56.1067 & 11.32609 \\
Government & & & &
\end{tabular}

Source: SPSS 26 data processing results (2021)

From the table above, tax compliance as the dependent variable proxied by tax effort has a minimum value of 0.03 for Bahrain and a maximum value of 0.96 for Norway. It shows that Bahrain has a low realization of tax revenue to its tax potential compared to Norway, with 0.96 or $96 \%$. It indicates that Norway has the highest tax effort among the 105 countries, implying having the highest tax compliance. The mean value of tax compliance is 0.4774 . It means that, on average, countries can obtain 0.4774 or $47.74 \%$ tax revenue out of their tax potential. Moreover, the standard deviation is $15.827 \%$ which means the data distribution is high. Financial crime proxied by money laundering/terrorist financing risk has a minimum value of 2.36 for Estonia and a maximum value of 7.82 for Laos. It shows that Laos has the highest vulnerability to money laundering/terrorist financing among 105 countries and has a low ability to combat it. The mean value is 5.0998 , which shows that, on average, countries have money laundering/terrorist financing risk that is relatively high as the data has a score ranging from 1 to 10 . Furthermore, the standard deviation is 1.10995 , which means that the spread of the data is high enough, and the data of financial crime is varied.

For the future orientation of government, it has a minimum value of 23.40 for Venezuela and a maximum value of 81.30 for Luxembourg. It shows that Luxembourg's government has a high ability to prepare for the future. It also ranks first out of 141 countries in the future orientation of government as reported in the Global Competitiveness Report 2019. The mean value of future orientation of government is 56.1067. It means that, on average, the ability of the governments of countries to adapt and commit to sustainability, or in other words, the ability of the governments of countries to prepare for the future is pretty high. Furthermore, the standard deviation is 11.32609 . It shows a high spread of data, which means that the data is presented variously.

\section{Classical Assumption Test}

Before the researcher tests the hypothesis, it is necessary to do a classical assumption test to know the feasibility of the regression model and to find out that the model is not biased. 
This research conducted a classical assumption test that included normality, multicollinearity, and heteroscedasticity tests. Because one test does not pass or meet the criteria, the data transformation was carried out using the square root data transformation (SQRT). This research has passed the classical assumption test after data transformation. The results of the tests are shown in Table 4 below.

Table 4. Classical Assumption Test Result

\begin{tabular}{lcll}
\hline \multicolumn{1}{c}{ Classical Assumption } & Model & \multicolumn{1}{c}{ Test Result } & \multicolumn{1}{c}{ Conclusion } \\
\hline Normality Test & 1 & Sig. 200>0.05 & $\begin{array}{l}\text { Passed } \\
\text { Passed }\end{array}$ \\
\hline Multicollinearity Test & 2 & Sig. 200>0.05 & Passed \\
& 1 & Tolerance $1.000>0.1$ & \\
& 2 & VIF $1.000<10$ & Tolerance $0.737>0.1$ \\
& & VIF $1.356<10$ & Passed \\
\hline Heteroscedasticity Test & 1 & Sig. $0.057>0.05$ & Passed \\
& 2 & Sig. $0.913>0.05$ & Passed \\
\hline
\end{tabular}

Source: SPSS 26 data processing results (2021)

The normality test results in both models have a significance value of more than 0.05 . Thus, it shows that the data are normally distributed and pass the normality test. Both models have the same results from of the multicollinearity test in which the tolerance is more than 0.1 and the Variance Inflation Factor (VIF) value is below 10. Hence, it shows that both models do not have multicollinearity problems and pass this test. For the heteroscedasticity test, both models have significance values of more than 0.05 . Therefore, it shows that both models pass the heteroscedasticity test.

\section{Hypothesis Test}

Based on Model 1 on table below, the regression coefficient of financial crime is 0.1052. The negative shows the negative influence of financial crime on tax compliance which means every 1 point increase in financial crime will reduce tax compliance by 0.1052 . The table also shows that financial crime has a significant influence on tax compliance, which is indicated by a significance value below 0.05 .

Table 5. Hypothesis Test Result

\begin{tabular}{lccccc}
\hline & \multicolumn{2}{c}{ Coefficient } & \multicolumn{2}{c}{ ANOVA } & \multirow{2}{*}{$\begin{array}{c}\text { Adj. R } \\
\text { Square }\end{array}$} \\
\cline { 2 - 5 } Model 1 & Beta & Sig. & F & Sig. & 0.0861 \\
FC & -0.1052 & 0.0014 & 10.7969 & 0.0014 & \\
\hline Model 2 & & & & & 0.2234 \\
FC & 0.7488 & 0.0131 & 10.9725 & 0.0000 & \\
FOG & 0.2903 & 0.0028 & 10.9725 & 0.0000 & \\
FC*FOG & -0.1046 & 0.0085 & 10.9725 & 0.0000 & \\
\hline Source: SPSS 26 data processing results (2021) & & &
\end{tabular}

Therefore, it shows that financial crime has a negative and significant influence on tax compliance. The higher the financial crime, the lower the tax compliance. Moreover, the Adjusted R Square for Model 1 is $8.61 \%$. It means that tax compliance is influenced by financial crime for $8.61 \%$, while other variables influence the rest.

Based on second model (Table 5), the significance value of the interaction variable of financial crime and future orientation of government is below 0.05 means that the future orientation of government can moderate the influence of financial crime toward tax compliance. Moreover, the regression coefficient of the interaction variable of financial crime and future orientation of government (b3) is -0.1046. The regression coefficient (b1) before being combined with the future orientation of government was -0.1052 . After being combined with 
The Influence of Financial Crime on Tax Compliance: Moderating Effect of Government's Future Orientation

Zahra Jihadia El Fitria Ramadhani and Ari Budi Kristanto

the future orientation of government, the regression coefficient (b3) becomes -0.1046 . Thus, when the government has a future orientation, the negative influence of financial crime on tax compliance can be reduced. Therefore, the future orientation of the government as the moderating variable can weaken the negative influence of financial crime on tax compliance. Furthermore, Table 5 also showed that Model 2 has an Adjusted R square of 22.34\%. It means that tax compliance is influenced by financial crime and the future orientation of government for by $22.34 \%$, while other variables outside of this research influence the rest.

\section{Discussion}

\section{Financial Crime on Tax Compliance}

Based upon the hypothesis tests that have been carried out, it is found that the first hypothesis is accepted in which financial crime has a negative influence on tax compliance. People committing financial crimes are people who disobey regulations. They will tend to violate or ignore the regulations. According to Amara \& Khlif (2018), money laundering describes the low conformity to the state regulations. Thus, it implies that a person who commits money laundering or related financial crime can also have low compliance with tax regulations as it is one of the state regulations. Furthermore, if someone commits a crime, they will tend to commit another crime. People will consider committing other crimes to increase their profits as long as they can launder it so that the authorities do not know about it and the offender can still enjoy the gains. Like someone who does money laundering, they will tend to consider tax evasion (Storm, 2013). Therefore, a high level of money laundering in a country indicates a high level of tax evasion. Tax evasion itself is an illegal act that shows tax non-compliance, so the higher the money laundering, the lower the tax compliance. Moreover, the high level of financial crime in a country can indicate the low performance of the government to combat financial crime. Thus, it can impact public trust, leading to low tax compliance. It is supported by Amara \& Khlif (2018) that the government that has a low commitment in combatting financial crime will discourage compliant taxpayers from complying with tax legislation which leads to tax non-compliance. Other than that, corruption by the government can influence tax compliance. An act of corruption is an act that violates the law and harms the state, which can lead to a decline in public trust in the government. When trust decreases, it can lead to a decrease in taxpayer compliance (Wu \& Teng, 2005). When the government commits corruption, the taxpayers will think and assume that the taxes they pay are not being used properly. Hence, it will reduce their compliance and impact decreasing tax revenue (Baum et al., 2017). Thus, it can be concluded that high financial crime can lower tax compliance. The research has in common with the previous research conducted by Amara \& Khlif (2018) that financial crime can lead to low tax compliance. The evidence's limitation is that the topics that directly address financial crimes and tax compliance are still limited, thus the supporting evidence may be insufficient.

\section{Future Orientation of Government on The Relationship of Financial Crime and Tax Compliance}

The second hypothesis in this study is that by changing the government's future direction, it will be possible to lessen the negative impact of financial crime on tax compliance. The future orientation of government is the government's ability to prepare for the future (World Economic Forum, 2018). Government adaptability, such as how responsive the government is to the changes like technology and digital, is an indicator of the future orientation of government (World Economic Forum, 2019). These things show the government's efforts to enhance the quality of life in society. In addition, a government that has policies and regulations related to energy efficiency, renewable energy, and ratified environmental agreements also shows the 
government's commitment to sustainability, which is an indicator of the government's future orientation (World Economic Forum, 2019). These conditions indicate the government's effort and commitment to protecting the environment so that the energy and the environment can be maintained for future generations. Therefore, with the government's efforts to enhance the quality of life and give prosperity to society, people will tend to trust the government. When public trust in the government is high, people will tend to comply with existing regulations (Stephens et al., 2019; Birskyte, 2014). The higher the public trust in the government, the higher the tax compliance as well (Birskyte, 2014). Moreover, according to Khlif et al. (2016), when the government has a strong commitment to improving welfare through sustainability, it can push the taxpayers to comply with tax legislation. Therefore, the future orientation of government tends to increase tax compliance. So, even though financial crimes occur in a country, but, when the government has future orientation, the researcher expects that the perpetrators of financial crimes or other taxpayers will respect it by complying with the tax regulations. Therefore, the government can still strive for tax compliance. The findings of this study are similar to those of Khlif et al. (2016)'s prior study on sustainability, which found that sustainability can influence tax compliance, with the higher the level of sustainability, the higher the tax compliance. As a result, the stronger the government's future orientation, the higher the tax compliance. However, this evidence has a flaw in that no study explicitly addresses the future orientation of government and tax compliance, therefore the supporting data may be weak.

\section{CONCLUSION AND SUGGESTION}

Based upon the research that has been carried out, financial crime has a negative influence on tax compliance. When financial crime is high, it indicates non-compliance behavior that people tend to not be compliant with regulations which can lead to low tax compliance. The higher the financial crime, the lower the tax compliance. This research supports Amara \& Khlif (2018) that financial crime can reduce tax compliance. Furthermore, the future orientation of government can weaken the negative influence of financial crime on tax compliance. The government that has a future orientation shows the government's awareness of the possibilities that will occur in the future and their efforts and strategies to prepare for them for the welfare of the society. With the government's efforts to make a prosperous society, people will tend to trust the government. The higher the public trust in the government, the greater the tax compliance as well (Birskyte, 2014). This research supports Khlif et al. (2016) that sustainability, as part of the future orientation of government, can increase tax compliance. Therefore, the government can still strive for tax compliance with future orientation even though financial crime is high.

This research provides information for the government in determining orientation strategies in response to the conditions of financial crimes that occur so that the government can still strive for tax compliance to maintain tax revenue as the main source of government revenue. The government can implement sustainability policies and be able to adapt to changes such as technology. In addition, this research also alerts the government regarding the importance of enforcing the law and combating financial crime. It is because financial crime has a huge impact on tax compliance and tax revenue which play an important role and contribute to financing the state.

The data used in this study has limitations because it comes from a variety of sources and years. As a result, readers should exercise caution when interpreting the findings of this study, and future researchers should use data from the same year to be more precise and detailed. Furthermore, this study can be used as a starting point for future research on themes such as financial crime, tax compliance, and government's future direction. This also leaves potential for future research to include other variables to enhance the study's findings. 
The Influence of Financial Crime on Tax Compliance: Moderating Effect of Government's Future

Orientation

Zahra Jihadia El Fitria Ramadhani and Ari Budi Kristanto

\section{REFERENCES}

Aghion, P., Akcigit, U., Cagé, J., \& Kerr, W. R. (2016). Taxation, corruption, and growth. European Economic Review, 86, 24-51. https://doi.org/https://doi.org/10.1016/j.euroecorev.2016.01.012

Alm, J., McClelland, G. H., \& Schulze, W. D. (1992). Why Do People Pay Their Taxes? Journal of Public Economics, 48, 21-38. https://doi.org/https://doi.org/10.1016/00472727(92)90040-M

Amara, I., \& Khlif, H. (2018). Financial crime, corruption and tax evasion: a cross-country investigation. Journal of Money Laundering Control, 21(4), 545-554. https://doi.org/10.1108/JMLC-10-2017-0059

Barbuta-misu, N. (2011). A review of factors for tax compliance. Annals of Dunărea de Jos University. Fascicle I: Economics and Applied Informatics. https://www.researchgate.net/publication/254404758_A_Review_of_Factors_for_Tax_C ompliance

Basel Institute on Governance. (2020). Basel AML index: 9th public edition ranking money laundering and terrorist financing risks around the world. https://www.baselgovernance.org/sites/default/files/2020-

07/basel_aml_index_2020_web.pdf

Baum, A., Gupta, S., Kimani, E., \& Tapsoba, S. J. (2017). Corruption, taxes and compliance. In IMF Working Papers (Working Paper No. 17/255). https://www.imf.org/en/Publications/WP/Issues/2017/11/17/Corruption-Taxes-andCompliance-45379

Birskyte, L. (2014). The impact of trust in government on tax paying behavior of nonfarm sole proprietors. Scientific Annals of Economics and Business, 61(1), 1-15. https://doi.org/10.2478/aicue-2014-0004

Borrego, A. C., Lopes, C. M. da M., \& Ferreira, C. M. S. (2013). Tax Noncompliance in an international perspective: Literature review. Contabilidade E Gestão - Portuguese Journal of Accounting and Management, 14(November), 9-41. https://www.researchgate.net/publication/285580068_Tax_Noncompliance_in_an_Intern ational_Perspective_Literature_Review

Carmi, N., \& Arnon, S. (2014). The role of future orientation in environmental behavior: analyzing the relationship on the individual and cultural levels. Society and Natural Resources, 27(12), 1304-1320. https://doi.org/10.1080/08941920.2014.928393

Devos, K. (2014). Factors influencing individual taxpayer compliance behaviour. https://doi.org/https://doi.org/10.1007/978-94-007-7476-6

Fenochietto, R., \& Pessino, C. (2013). Understanding countries' tax effort. In IMF Working Papers (Working 13/244). https://www.imf.org/external/pubs/ft/wp/2013/wp13244.pdf

Gottschalk, P. (2010). Categories of financial crime. Journal of Financial Crime, 17(4), 441458. https://doi.org/10.1108/13590791011082797

Handoyo, S., \& Candrapuspa, H. M. (2017). Knowledge of fraud and taxpayer compliance. Jejak, 10(1), 385-397. https://doi.org/10.15294/jejak.v10i2.11303

ICTD/UNU-WIDER. (2020). Government Revenue Dataset. https://www.wider.unu.edu/project/government-revenue-dataset

IMF. (2001). Financial system abuse, financial crime and money aundering - background paper (Policy Papers 2001/039). https://doi.org/https://doi.org/10.5089/9781498328104.007

Johnson, S. (2018). Corruption is costing the global economy \$3.6 trillion dollars every year. 
Big Think. https://www.weforum.org/agenda/2018/12/the-global-economy-loses-3-6trillion-to-corruption-each-year-says-u-n

Johnson, S. R. L., Blum, R. W., \& Cheng, T. L. (2014). Future orientation: A construct with implications for adolescent health and wellbeing. International Journal of Adolescent Medicine and Health, 26(4), 459-468. https://doi.org/10.1515/ijamh-2013-0333

Jung, J., \& Lee, J. (2017). Contemporary financial crime. Journal of Public Administration and Governance, 7(2), 88-97. https://doi.org/10.5296/jpag.v7i2.11219

Junpath, S. V., Kharwa, M. S. E., \& Stainbank, L. J. (2016). Taxpayers' attitudes towards tax amnesties and compliance in South Africa: an exploratory study. South African Journal of Accounting Research. https://doi.org/10.1080/10291954.2015.1070565

Kar, D., \& Spanjers, J. (2015). Illicit financial flows from developing countries: 2004-2013 (Issue December). https://gfintegrity.org/report/illicit-financial-flows-from-developingcountries-2004-2013/

Khlif, H., Guidara, A., \& Hussainey, K. (2016). Sustainability level, corruption and tax evasion: a cross-country analysis. Journal of Financial Crime, 23(2), 328-348. https://doi.org/https://doi.org/10.1108/JFC-09-2014-0041

Kumar, V. A. (2012). Money laundering: Concept, significance and its impact. European Journal of Business and Management, 4(2), 113-120. https://www.iiste.org/Journals/index.php/EJBM/article/view/1040/960

La Porta, R., Lopez-de-Silanes, F., Shleifer, A., \& Vishny, R. (1999). The quality of government. Journal of Law, Economics, and Organization, 15(1), 222-279. https://doi.org/https://doi.org/10.1093/jleo/15.1.222

Langford, B., \& Ohlenburg, T. (2015). Tax revenue potential and effort investigation. In International Growth Centre. https://www.theigc.org/wpcontent/uploads/2016/01/Langford-Ohlenburg-2016-Working-paper.pdf

Lewin, K. (1926). Intention, will, and need. In D. Rapaport (Ed.), Organization and Pathology of Thought (pp. 95-151). Columbia University Press. https://doi.org/https://doi.org/10.7312/rapa92214-008

Long, S. B., Swingen, J. A., Roth, J. A., Scholz, J. T., \& Witte, A. D. (1991). Taxpayer compliance: Setting new agendas for research. Law \& Society Review, 25(3), 637. https://doi.org/https://doi.org/10.2307/3053731

Mawejje, J., \& Sebudde, R. K. (2019). Tax revenue potential and effort: Worldwide estimates using a new dataset. Economic Analysis and Policy, 63, 119-129. https://doi.org/10.1016/j.eap.2019.05.005

Mayowan, Y. (2019). Tax morale and tax compliance. 93, 264-267. https://doi.org/https://doi.org/10.2991/aicobpa-18.2019.60

Murphy, R. (2011). Collect the evaded tax, avoid the cuts. The Guardian. https://www.theguardian.com/commentisfree/2011/nov/25/evaded-tax-evasion-cuts

Nurkhin, A., Novanty, I., Muhsin, M., \& Sumiadji, S. (2018). The influence of tax understanding, tax awareness and tax amnesty toward taxpayer compliance. Jurnal Keuangan Dan Perbankan, 22(2), 240-255. https://doi.org/10.26905/jkdp.v22i2.1678

OECD. (2010). Tax compliance and tax accounting systems. In Centre for Tax Policy and Administration (Issue April). http://www.oecd.org/tax/forum-on-taxadministration/publications-and-products/technologies/45045662.pdf

OECD. (2019). Government at a glance 2019. OECD Publishing. https://doi.org/https://doi.org/10.1787/8ccf5c38-en

Petutschnig, M. (2017). Future orientation and taxes: Evidence from big data. Journal of International Accounting, Auditing and Taxation, 29, 14-31. https://doi.org/10.1016/j.intaccaudtax.2017.03.003

Picur, R. D., \& Riahi-Belkaoui, A. (2006). The impact of bureaucracy, corruption and tax 
The Influence of Financial Crime on Tax Compliance: Moderating Effect of Government's Future Orientation

Zahra Jihadia El Fitria Ramadhani and Ari Budi Kristanto

compliance. Review of Accounting and Finance, 5(2), 174-180. https://doi.org/10.1108/14757700610668985

Randlane, K. (2015). Tax compliance as a system: mapping the field. International Journal of Public Administration, 39(7), 515-525. https://doi.org/10.1080/01900692.2015.1028636

Schneider, F., Raczkowski, K., \& Mróz, B. (2015). Shadow economy and tax evasion in the EU. Journal of Money Laundering Control, 18, 34-51. https://doi.org/https://doi.org/10.1108/JMLC-09-2014-0027

Seginer, R., \& Noyman, M. S. (2005). Future orientation, identity and intimacy: their relations in emerging adulthood. European Journal of Developmental Psychology, 2(1), 17-37. https://doi.org/10.1080/17405620444000201

Slemrod, J., \& Katuščák, P. (2005). Do trust and trustworthiness pay off? Journal of Human Resources, 40(3), 621-646. https://doi.org/10.3368/jhr.xl.3.621

Stephens, M., El-Sholkamy, M., Moonesar, I. A., \& Awamleh, R. (2019). Future governmentsactions \& insights (Volume 7, Issue February). Emerland Publishing Limited. https://doi.org/10.1108/s2048-757620197

Storm, A. (2013). Establishing the link between money laundering and tax evasion. International Business \& Economics Research Journal (IBER), 12(11), 1437-1450. https://doi.org/https://doi.org/10.19030/iber.v12i11.8181

Tax Justice Network. (2021). The State of Tax Justice 2021 (Issue November). https://taxjustice.net/reports/the-state-of-tax-justice-2021/

United Nation. (2005). Economic and financial crimes: Challenges to sustainable development (Eleventh United Nations Congress on Crime Prevention and Criminal Justice). https://www.unodc.org/pdf/WP on item 6 V0581301 in English.doc

Varvarigos, D. (2017). Cultural norms, the persistence of tax evasion, and economic growth. Economic Theory, 63, 961-995. https://doi.org/10.1007/s00199-016-0976-1

Wardani, D. K., \& Juliani. (2018). Pengaruh tax avoidance terhadap nilai perusahaan dengan corporate governance sebagai variabel pemoderasi. Jurnal Nominal, VII(02), 47-61. https://doi.org/https://doi.org/10.21831/nominal.v7i2.21349

Wentworth, N. (2008). Future orientation. Encyclopedia of Infant and Early Childhood Development, 562-574. https://doi.org/https://doi.org/10.1016/B978-0123708779.00068-2

World Economic Forum. (2018). The Global Competitiveness Report 2018. In K. Schwab (Ed.), World Economic Forum. World Economic Forum. http://www3.weforum.org/docs/GCR2018/05FullReport/TheGlobalCompetitivenessRep ort2018.pdf

World Economic Forum. (2019). The global competitiveness report 2019. In K. Schwab (Ed.), World Economic Forum. World Economic Forum. http://www3.weforum.org/docs/WEF_TheGlobalCompetitivenessReport2019.pdf

World Economic Forum. (2020). The global competitiveness report: How countries are performing on the road to recovery. In K. Schwab \& S. Zahidi (Eds.), World Economic Forum. World Economic Forum. www3.weforum.org/docs/WEF_TheGlobalCompetitivenessReport2020.pdf

Wu, S.-Y., \& Teng, M.-J. (2005). Determinants of tax compliance - a cross-country analysis. FinanzArchiv/Public Finance Analysis, 61(3), 393-417. https://doi.org/https://doi.org/10.1628/001522105774979001

Youde, S., \& Lim, S. (2019). Tax compliance. Global Encyclopedia of Public Administration, Public Policy, and Governance, 1-5. https://doi.org/https://doi.org/10.1007/978-3-31931816-5_3828-1 